\title{
CONTEXTUALISING LAW: AN ATTEMPT TO OPERATIONALISE THEORY BY TEACHING INTERVIEWING IN THE LAW SCHOOL
}

\author{
ALAN LEAVER*
}

\section{INTRODUCTION}

In the Pearce Report three major goals of law schools were identified as similar to those of universities: to undertake research; to service the community; and to teach. ${ }^{1}$ Achievement of the last goal required going beyond the mere "imparting of knowledge" to include (among other things) an understanding of the law in operation as well as in context, and to develop in students practical legal skills and competencies that were essential to all types of legal work, notwithstanding the degree of separation of that work from the practice of law. ${ }^{2}$ The recommendation was made that this objective could be achieved by teaching specific practical legal skills such as advocacy, communication, counselling, drafting, interpretation of legislation, negotiation, and research and writing. ${ }^{3}$

One inference to be drawn from the above recommendation is that the teaching of law can be improved, and the perceived separation of the theory and the practice of law narrowed to some extent, by incorporating practical legal skills into the curricula of law schools. This hypothesis, that teaching and learning of law can be optimised by creating and maintaining a substantial and realistic nexus between legal theory and legal practice, ${ }^{4}$ finds support from recent research in general educational theory and methodology of other practice-based professions. ${ }^{5}$ However, research in Australia to support that hypothesis in regard to law in the interim since the publication of the Pearce Report appears to remain limited if special issues of periodicals, ${ }^{6}$ specialist periodicals ${ }^{7}$ and projects supported by the Committee for the Advancement of University Teaching ${ }^{8}$ can be relied upon as indicators of research. This alleged limitation exists notwithstanding attention being brought by the Pearce Report to the relative paucity of writing, and to the almost absolute absence of empirical data, on legal education. ${ }^{9}$

A movement towards incorporation of such a practical approach, endorsed at the time of publication of the Pearce Report by some commentators ${ }^{10}$ and subsequently supported by others, ${ }^{11}$ has occurred since the release of the Pearce Report, especially in newly established law schools which have been innovative to varying degrees, ${ }^{12}$ thanks in part to support from the Committee for the Advancement of University Teaching. This paper describes one such innovation in legal education, the teaching of interviewing skills as an addition to the mooting component of the criminal law course, adopted at the Law School of the Flinders University of South Australia and supported by a grant from the Committee for the Advancement of University Teaching during 1994. The mooting framework of the criminal law curriculum into which the interviewing project was placed is detailed before outlining the educational theory that justifies the choice of interviewing. The interviewing project is then briefly described.

\section{MOOTING FRAMEWORK}

At Flinders University, the initial Curriculum Committee of the Law School took into consideration recommendations of the Pearce Report, especially those relating to skills, and committed itself to incorporate those skills into the curriculum as far as possible. That commitment was demonstrated by the intention expressed in the Curriculum Proposal to lay "a foundation in appropriate legal skills on which the experience of the GDLP ${ }^{13}$ and subsequent practice can build". ${ }^{14}$ In 1992, the first year of operation, that 
commitment was realised by the appointment of a former Supreme Court Justice as Skills Director ${ }^{15}$ the inclusion of research and of fact finding skills as integral elements of the compulsory topic Torts and Legal Method. ${ }^{16}$ In 1993, that commitment took effect as part of the substantive course or as a method of assessment, or both, in the following ways: drafting became a requirement of Contract Law; electronic Land Title searches were undertaken in Property Law; and mooting was made part of the assessment of Criminal Law. In addition, criminal law students had the opportunity to view procedural aspects of criminal law, from arrest through a bail application to committal, trial and sentencing. This programme was simulated by the criminal law teachers in order to place the teaching of the theory of criminal law in context by demonstrating the connection between the theory and practice of criminal law. ${ }^{17}$

Criminal Law was taught for the first time in the Law School at the Flinders University of South Australia in 1993. That course included a significant component of practical legal skills for, in addition to legal research and writing requirements as part of assessment, students were required to moot. ${ }^{18}$ They were given hypotheticals, written by the two criminal law teachers, containing facts and grounds of appeal against a decision at first instance on the subject of homicide. From these hypotheticals, students prepared written and oral arguments on points of law for presentation and assessment. Although these written and oral arguments were respectively prepared and delivered by students individually, the roles of counsel representing appellants and respondents were each allocated to pairs of students, thus encouraging levels of cooperation and collaboration that frequently occur in practice. Oral presentations were made before an appellate judge, a role played by visiting practitioners not connected with the law school, unless unavailable, when other teachers within the law school or the criminal law teachers assumed this role. ${ }^{19}$

There is, of course, nothing novel in this method. In recent years, written and oral arguments (usually in the form of moots) have become relatively commonplace as elements of assessment in Australian law schools. ${ }^{20}$ This method was adopted by the criminal law teachers as the most appropriate to develop oral legal skills within the limits of available resources. However, following analysis of assessment of students' performances in moots, and of evaluation by students of the mooting programme, the criminal law teachers became concerned that moots might not be satisfying the requirement of foundation legal skills. That is, moots appeared not to provide the bridge necessary for students to move from social skills to the fundamentals of lawyering skills. That concern arose primarily because oral arguments invariably became spoken versions of written arguments. In addition, student evaluation indicated that, whereas most students appreciated the importance and relevance of mooting, this majority also felt inadequately prepared for the task of an oral presentation, especially as most had not performed comparable tasks previously. In methodological terms, students had no reference points and minimal or nil experience on which to draw and build so that experiential learning could not be relied upon in mooting.

Whatever the explanation for this perceived deficit, the consequence is that oral skills did not appear to develop to the same extent as writing skills. Yet, these oral skills should be considered to be at least as important as writing skills because legal workers, notwithstanding the degree of connection of their legal work with the actual practice of law, rely upon them to find facts in the first instance, especially in interviews. And, connections made between interviewing and research for preparation of written and oral arguments help to demonstrate to students the continuity that is the reality of the practice of law besides reminding them that this work is not undertaken solely as an abstract exercise, but for the important purpose of providing an essential service to someone in need. Put another way, the teaching of practical legal skills, such as those inherent in the process of interviewing in combination with the teaching of legal theory, helps to place both aspects of teaching, theory and practice, in the context of "lawyering".

These initial concerns about the effectiveness of accepted methods of teaching law, such as mooting, generated further inquiry into alternative methods of teaching practical legal skills that would lay better foundations for future acquisition of these skills. That inquiry demanded a conceptual analysis of general and legal educational methodology in an attempt to justify any change.

\section{JUSTIFICATION FOR CHANGE}

The inquiry mentioned above led to a focus upon deficiencies, alleged to exist in the teaching, learning and assessment of law as a practice-based discipline, that have been highlighted by many commentator ${ }^{21}$ 
and researchers. ${ }^{22}$ Those deficits can be analysed under these same headings.

\section{Teaching and Learning ${ }^{23}$}

The traditional approach to teaching and learning law is alleged by some commentators and researchers to be too narrow as a result of the placement of the emphasis upon content in curricula to the exclusion of an consideration of teaching methodology and of assessment. ${ }^{24}$ Therefore, it may be inferred that opportunities to adopt approaches that broaden teaching and learning are reduced. Approaches that achieve this objective and are worthy of consideration within the teaching and learning of law are holism and humanism because the are taken into account by other practice-based disciplines. ${ }^{25}$ These concepts require brief elaboration.

\section{HUMANISM}

Humanism is a philosophical perspective alleged to derive from the approach of the philosopher Dilthey to the study of human sciences (comprising humanities and social sciences). That approach goes beyond empiricism to include consideration of the effects of human behaviour upon the content and results of that empirical investigation. ${ }^{26}$ The effect is to acknowledge that all investigation cannot be separated from the investigator's influence arising, inadvertently or otherwise, from the personal experience of that investigator.

Humanism places the individual at the centre of the education process. ${ }^{27}$ by recognising the degree to which individuals rely upon experience for learning. Experiential learning is the process by which persons learn from their personal experience by analysing past behaviour and using that analysis to predict and plan future conduct. ${ }^{28}$ The experiential learning model is incorporated into practical legal skills programmes by the use of simulation techniques, ${ }^{29}$ such as interviewing. First, students are given factual scenarios, replicating those encountered in practice, for which they are required to develop a response which optimises results for the "client". This response is known as a "theory of action". Lawyering activity appropriate to the response then follows before reflection to improve this theory of action. That new theory is then applied to new simulations. In short, students learn by doing, another recommendation contained within the Pearce Report.

This learning becomes cumulative, in that it builds upon all experience, thus facilitating the development of autonomy, responsibility, interpersonal awareness and personal growth by means of reliance upon experiential learning. ${ }^{30}$ The importance of experience has been highlighted in the context of clinical legal education by one commentator who describes that form of legal education as a "method of teaching and learning, the distinctive element" of which is "its emphasis on structured student experience and thoughtful feedback on that experience as the core of learning ${ }^{31}$ (emphases added).

The assertion that much is to be gained through doing, that is through experience, also seems to gain support from the eminent jurist, Professor Simpson, when he asserts: "[y]ou can only usefully study law if you have learnt ... what it is to be a lawyer" so that "involvement in the more traditional professional approach is a necessary prerequisite to anything more sophisticated". ${ }^{32}$ If the "traditional professional approach" can be taken to mean practice, then the claim that knowledge of practice is a condition precedent for higher levels of learning appears to point to the conclusion that a more sophisticated approach to the study of law, for example from all theoretical and critical dimensions (also recommendations by the Pearce Report ), is more likely if students learn to be lawyers in practice as well as in theory. Learning to do thus integrates learning to know, so that law is learnt in a similar manner to the way in which most knowledge is learnt and understood - through socialisation building on existing experience. This proposition regarding experience is supported by general educational research and methodology which indicates that, androgogically, past experience can be a base upon which new learning is built. ${ }^{33}$

What humanism promises for law is learning that becomes more active than passive, ${ }^{34}$ encouraging students to become self-motivated enough to be self-directed towards higher levels of critical reasoning, all of which are essential to developing professionals who can not only adapt to but also participate in change. ${ }^{35}$ Self-direction is an essential skill to be developed in relation to teaching and learning law in an academic environment because that capacity is and will remain a permanent requirement of the practice of 
law in all arenas, as is the case with all practice-based professions. It is also directly connected with becoming an autonomous decision maker. ${ }^{36}$ So important is self-direction that it has been asserted that not to encourage that capacity is to "perpetuate a dysfunctional relationship between learner and educator". ${ }^{37}$

Furthermore, it should be recognised that humanism, by virtue of its derivation from Dilthey's theory of knowledge of human sciences, is directly connected with holism ${ }^{38}$ because all understanding of empiricism is dependent upon an understanding of the context in which that empirical investigation takes place. In other words, relationship and connection between the whole and the parts cannot be excluded from the equation, for not only can the whole only be understood in light of its parts but also the parts derive their meaning from the whole. ${ }^{39}$

\section{HOLISM}

Holism can be argued to be anti-reductionist in approach in that what is required is recognition of the importance of the contribution of knowledge from many rather than from only single perspectives. For the teaching and learning of law that means the inclusion of theory, of all types, and of professional skills. The McCrate Report goes further, advocating the "adoption of a holistic view to legal education which occurs through a developmental continuum of pre-law school education, law school and legal practice" ${ }^{40}$ (emphasis added). With holism, the focus is upon relationships and interconnections ${ }^{41}$ not only between facets of law but also between law and other academic areas. In other words, more complete integration as recommended by the Pearce Report is possible.

In addition to facilitating integration in the teaching of law, holism can be supported for several other reasons. First, holism can be described as a feminine world-view ${ }^{42}$ because that view tends to be inclusive rather than exclusive of other perspectives. Hence, the allegedly inherent masculine view of law may be balanced by shifting the focus towards one that is gender free through listening to Gilligan's "different voice". ${ }^{43}$ Second, holism can be argued to be compatible with the doctrine of post-modernism if both holism and post-modernism are accepted as devaluing individual and favouring pluralistic approaches. ${ }^{44}$ Third, it is worth noting that holism has been enthusiastically embraced by practice-based disciplines other than law, especially those that come under the rubric of behavioural sciences, not only particularly with respect to teaching but also generally in regard to developing an epistemological base. ${ }^{45}$

In short, the thesis formulated by holism is that knowledge is acquired through understanding parts of the world and their relationship with the whole. In relation to the teaching of law, the effect of holism is to work against the traditional fragmented approach to teaching law that may result in students failing to recognise immediately the connections within law.

In addition to the above, other important arguments put forward to support the assertion that the teaching and learning of law are too narrow are that it is neither contextual nor genuinely problem based. These concepts will be considered briefly.

\section{CONTEXTUAL}

Where teaching of law relies on doctrine derived from appellate cases the study of law tends to be separated from a significant part of the reality in which law operates. Contextual learning, that is "learning in the context in which it is to be applied" ${ }^{46}$ facilitates understanding of the relationships and connections not only between areas of law but also between law and other disciplines (practice-based or otherwise) such as economics, history, sociology and psychology, to name a few. Although there is no doubt that legal practitioners can serve their clients satisfactorily without arguing theoretical issues, there is also no doubt that their practice of law must benefit from an awareness of the context in which that practice operates. ${ }^{47}$ For example, the battered woman syndrome as a defence in criminal law could only develop from an awareness of the sociological and psychological concepts underpinning that syndrome. This emphasis upon links reiterates the theses of holism and humanism.

\section{PROBLEM-BASED LEARNING}

The claim that the teaching of law is problem-based appears to rely on the use of hypotheticals to which 
legal principles are applied. However, this method does not constitute problem-based learning as defined by its doyen, Barrows, ${ }^{48}$ because the approach is too individualistic. Whereas traditional teaching of law in Australia, including the use of problems, ${ }^{49}$ tends to encourage an individualistic approach to learning because collective discussion of the problem usually takes place after a solution has been sought by the student as an individual not as part of a group, ${ }^{50}$ genuine problem-based learning demands both cooperation and collaboration during the attempt to seek the solution. In reality, problem-based learning is a form of peer-teaching and peer-learning. ${ }^{51}$ It is in those contexts that problem-based learning is considered here because of the opportunities that interviewing provides for peer-teaching and peer-learning.

Teaching by and learning from peers appears to encourage deeper approaches to learning than otherwise possible ${ }^{52}$ because students develop specific learning skills which last. They learn to listen and absorb information rather merely hear it so that they can make valid comparisons between their own and peer understanding. This, in turn, leads to information-seeking from, and correction of, others in non-threatening ways, especially where tasks are allocated to each other. ${ }^{53}$ Peer-learning also facilitates the development of self-directed learning by encouraging both informal and formal levels of cooperation and collaboration. ${ }^{54}$

Problem-based learning has been enthusiastically embraced by many teachers of practice-based disciplines because it is believed to overcome what has been asserted to be the passive, uncritical and pragmatic acceptance by students of lecture content, which process allegedly fails to equip practitioners for self-motivated and self-directed learning. ${ }^{55}$ Problem-based learning equips students by developing and maintaining creative and critical reasoning. This approach can assist the development of professionals who are not only capable of adapting to change but are also able to play an active role in bringing about that chang $\mathrm{e}^{56}$ because significantly deeper rather than superficial approaches to learning are possible. ${ }^{57}$

\section{Assessment}

Assessment is used here as defined by Professor Brookfield. ${ }^{58}$ That is, assessment is an attempt to discover the degree to which objectives in teaching have been reached by ascertaining the extent of learning of students. Used in that sense, assessment is "summative" in that what is measured is the acquisition of "certain knowledge, skills, values and attitude ${ }^{59}$ so that assessment becomes a "certification of an individual's knowledge and abilities". ${ }^{0}$ Assessment is not to be equated, as is often the case, with evaluation which is the ascertainment of merit.

Assessment is not to be underrated in importance. It is neither a mere adjunct nor an "afterthought" 61 to teaching and learning but integral to the topic assessed because assessment bears a direct relationship to the quality of learning outcomes. ${ }^{62}$ It is a "teaching and learning tool rather than a mechanism for grading"63 and must be linked to learning. ${ }^{64}$ If, as Barnes asserts, assessment becomes a "hidden curriculum"65 which sends messages to students about how and what they should study, then assessment can and should be tailored to optimise student learning. Expressed another way, assessment becomes the means to the ends desired in relation to student acquisition of knowledge and skills. Furthermore, if assessment shapes attitudes to learning in the manner described, then it can be used to direct students towards those deeper approaches to learning argued above to be desirable. Consequently, the method of assessment becomes critical.

The Pearce Report highlighted the fact that the method of assessment in law schools was predominantly by means of examination. ${ }^{66}$ Although since the publication of the Pearce Report the most common change in assessment has been a "reduction in emphasis on examinations", recent changes in assessment have been forced by resource problems to the extent that use of examinations has increased. ${ }^{67}$

The advantages and disadvantages of examinations have been well documented and require no repetition here. However, it is worth reiterating that one of the major complications of examinations is that, unlike other forms of assessment, they are designed to measure rather than teach. ${ }^{68}$ Therefore, they will not direct student learning as thoroughly as other methods of assessment. Thus, notwithstanding recent trends towards an increase in interim assessment, usually in the form of essays, if assessment in law schools still appears to rely mainly upon written responses to hypothetical fact scenarios, usually by examination, then assessment in that form will remain an adjunct and afterthought. Consequently, the effectiveness of forms of assessment other than examination remains essentially untested, despite the demonstrated benefits of those alternative assessments. For example, the fact that the use of self- and peer-assessment as alternatives 
to traditional forms of assessment in law schools appears to be the exception rather than the rule merits concern because both appear to be crucial to the effective integration of teaching and of learning both theory and practice of law.

\section{Self-assessment}

By encouraging a continuous process of critical reflection of one's own work ${ }^{70}$ self-assessment facilitates the transition from law school to work because students skilled in self-assessment are likely to be more effective, efficient and able to effect transfers across learning boundaries. ${ }^{70}$ This should mean that qualifications in law become more versatile in their application to work so that a wider choice of occupations is possible. Law thus becomes generalisable to other non-law areas at least to some degree. The negative effect of the relative absence of reference points and experience upon which to found the teaching and learning of law can thus be reduced.

\section{Peer-assessment}

Peer-assessment may, at first instance, appear novel. However, on reflection, it should be recognised that it is already in place in many practice-based disciplines in teaching and learning environments. It is widely used at both undergraduate and postgraduate levels in many behavioural science disciplines, especially medicine and nursing. In disciplines other than behavioural sciences, postgraduate seminars, where peers critique each others' work-in-progress under the guidance of teachers, are commonplace. Furthermore, although that type of analysis is not formally incorporated into official assessment processes it seems unlikely that it would not exert at the least a de facto effect.

At the level of practice rather than teaching and learning in institutions, peer-assessment is widely used by most practice- based disciplines and is rapidly being formalised by Quality Assurance Committees internally and by accreditation bodies externally, particularly in relation to health care workers. In the workplace, regulation of practitioners in practice-based disciplines is invariably internal and effected by means of peer-review, as with medical practice. This existing level of peer-assessment appears to merit consideration for inclusion in law curricula because the addition of a practice-based activity to an academic teaching and learning environment would appear to facilitate that transition from (law) school to (law) practice.

In summary, to optimise teaching and learning of law, it appears that research points to the conclusion that curricula should be humanistic, holistic, contextual and genuinely problem-based. In addition, assessment should be an integral part of that teaching and learning, not an adjunct. In this way, the connection with and transition between legal doctrine in, and practice outside, law school can be established and maintained, and the tendency for law students to discern law as fragments, especially with regard to theory and practice, can be reduced.

At this point, the Criminal law teachers faced the question of how best to implement these ideals of teaching and learning law. The rationale for change had been justified, conceptually. However, what practical process, other than mooting, could be implemented that would bring about these objectives? The criminal law teachers set out to identify a process that would achieve those satisfactorily. In light of the time requirements of mooting, we were concerned particularly about the resource implications of incorporating practical components into what was a compulsory law topic already comprising, especially from the perspective of law students, a dense content of substantive law and a significant component of practical legal skills.

\section{IDENTIFICATION OF THE PROCESS}

In their search for a process that would lay better foundations than mooting alone for learning practical legal skills, at least at foundation level, the criminal law teachers were aware of the need to maintain quality in teaching and learning in relation to any programme adopted. Bearing in mind the elusive nature of a definition of quality ${ }^{71}$ the problem of defining quality was solved by adopting the requirements for, and the recommendations on how to determine, quality for teaching and learning contained in the recently published Quality Reports from both The University of Adelaide and The Flinders University of South 


\section{Australia. $^{72}$}

Those requirements included, amongst others, the introduction of interactive and student-centred methods, team approaches, peer teaching, experiential learning, and appropriate assessment: in short, all the concepts discussed and argued as essential in the rationale for change in this paper. The recommendations necessitated asking the questions concerning intentions and implementations found in these Reports. ${ }^{73}$ Intentions comprised: What are you doing?; Why are you doing it? Implementations were composed of: How are you doing it?; Why are you doing it this way?; Why do you think that is the best way of doing it?; How do you know it works? These questions then directed the criminal law teachers towards the following considerations. ${ }^{74}$

Q: As professionals, what is the most important work lawyers do, whether practitioners or nonpractitioners?

A: Provide a service to others, mostly clients.

Q: By what means is this service provided?

A: By communicating to non-lawyers and lawyers principles of the law as they apply to facts.

Q: Does this task vary between practitioners and nonpractitioners?

A: Not significantly enough to warrant a separate approach for each.

Q: What is the predominant method of communication?

A: Personal contact between lawyers and others.

Q: Bearing in mind the requirements of content in compulsory topics (especially in relation to admission) and the predominant method of communication, how can that content be taught so as to optimise the performance of a lawyer's most important task of communication?

A: Teach interviewing skills.

\section{JUSTIFICATION FOR INTERVIEWING}

Having arrived at a solution capable of being implemented within the criminal law course and within the limits of available resources, the criminal law teachers sought additional justification in support of this perceived solution because the addition of the process of interviewing to mooting as described above can, of course, be considered as no more novel than the use of mooting itself. After all, interviews are often undertaken preparatory to making simulated bail applications and presenting guilty pleas in most postgraduate, practical legal training courses.

However, in the environment of postgraduate practical legal training courses, the tendency still exists for students to compartmentalise law and to perceive there to be a dichotomy between the theory and practice of law. ${ }^{75}$ The connection between the practice of interviewing and the theory of law remains tenuous because practical legal skills are still taught in isolation from the reality of the continuity that exists in reality between practice and theory. In other words, there are connections between practice and theory in that facts discovered during interviewing provide direction for research into specific areas of law, the results of which determine the need for and thrust of further interviews, for additional direction of research and for legal principles that support the remedy sought. The point being made has already been put by Mack, who places interviewing in context, in relation to learning interviewing techniques in the law school rather than in a postgraduate legal practice course. Mack states that interviewing has a "much broader and more theoretical direction" than the development of skills alone because interviewing "facilitates the academic examination of the lawyering process itself, which is an essential part of the legal system". ${ }^{76}$ Support for the placement of the teaching and learning of communication skills into law schools has also been expressed in the United Kingdom. ${ }^{77}$

Many other legal bodies and commentators support the importance of interviewing in relation to lawyering, and have for some time. For example, in a report published in 1979, the American Bar Association described interviewing as an essential element of "lawyer competency". ${ }^{78}$ In 1980, MenkelMeadow stated that the core function of lawyers is to advise and represent clients by communicating the law to non-lawyers and lawyers. ${ }^{79}$ More recently, in 1986, Sherr went further, asserting that the "first interview between lawyer and client is the foundation of a legal case" ${ }^{80}$ It would, therefore, appear reasonable to assert that at no other point on the continuum of contact between lawyer and client is the 
initial discovery of facts so crucial as at the first meeting between lawyer and client.

Reliance can also be placed upon comments made by criminal law students who studied interviewing at the Law School at the Flinders University of South Australia in $1993 .^{81}$ Their comments point to the conclusion that contact with clients in a face-to-face interview is contemplated with apprehension by most and dreaded by some, especially the first time. The explanation appears to be not the relative lack of legal knowledge perceived as necessary to direct the interview towards discovery of relevant facts but rather the obvious need to develop a rapport with the client to optimise discovery of facts. In this respect, again, most students have nil personal reference points: that is, they have limited or no personal experience on which to draw. ${ }^{82}$ Students are aware that the development of a positive perception on the part of the client, and of credibility and professionalism on the part of the lawyer, depends as much upon personal skills as upon legal knowledge. The validity of this observation is borne out by recent investigations, particularly overseas.

At an American Bar Association Convention in New York in 1993, attended by 12000 lawyers of whom about 500 came from outside the United States, one of the Convention topics was the perception of the legal profession by the public. It was reported that research by the American Bar Association showed that one factor influenced the public perception of lawyers more than any other - the ability to communicate. ${ }^{83}$ Reports also indicate that a similar situation exists in the United Kingdom. ${ }^{84}$ This aim is supported by data contained in a report from the Royal Commission (UK) on the Provision of Legal Services (Benson Committee). This report showed that "poor communication is the major reason for dissatisfaction" of clients with solicitors. Since the client/solicitor relationship and communication normally begin with an interview of the client by the solicitor, it follows that skills in interviewing are important to lawyering because that initial point of contact between lawyer and client would appear to be essential to establishing relationships and discovering facts.

In short, it is the context that is important. if foundation ${ }^{85}$ practical legal skills, as found in the process of interviewing, are taught in the context of the teaching of legal theory, then law students are likely to develop not only those skills but also to use those skills to enhance their understanding of legal theory. ${ }^{86}$ The outcome should be synergistic in that the learning of both aspects of lawyering - practice and theory — will enhance each other.

Whatever the emphasis on the role of interviewing, whatever the claims made for the benefits of possessing interviewing skills, there appears to be no doubt that there is agreement between many commentators with respect to the importance of interviewing as an integral component of foundation practical legal skills. The inclusion of interviewing into a practical component of a law course, such as Criminal Law, therefore, seemed to be an appropriate method of testing that importance, thereby facilitating the development of that more complete lawyer, a foundation on which postgraduate practical legal training courses and experience can build. And that concept appears to be an expectation of law students ${ }^{87}$ and the profession..$^{88}$

In reliance on the results of this investigation, interviewing was introduced into the Criminal Law course at the Law School of Flinders University.

\section{INTERVIEWING IN CRIMINAL LAW}

Interviewing was added to the framework of mooting in Criminal Law during 1994. Instead of providing a written hypothetical to a single law student, it was given to a student playing the role of a witness/interviewee. That written hypothetical described an offence witnessed by this student/ witness/interviewee (hereafter interviewee) plus a decision of a court at first instance from which grounds of appeal could be raised.

The role of witness was preferred to that of a defendant because, as there is no property in witnesses, ${ }^{89}$ there is no impediment to either counsel for the defendant/appellant or for the prosecutor/respondent interviewing witnesses and to the revelation of facts to either these counsel by the witness. Interviewing of defendants by counsel for the respondent as prosecution would import an entitlement on the part of the defendant to assert a right to silence, thereby defeating the purpose of the interview to discover facts.

This interviewee was not a law student but a senior drama student. There were reasons for this choice. 
First, drama students generally have no more knowledge of the law than the usual witness and cannot therefore assist, even inadvertently, the law students conducting the interviews as lawyers. Second, as drama students would bring a higher degree of professionalism to the role than might be expected from law students generally, it was anticipated that drama students would give the role of witness a credibility that would compel law students to treat the interview seriously. ${ }^{90}$ Third, as drama students are taught and required to apply principles of semiotics of language and of voice, ${ }^{91}$ the potential existed to assess law students' abilities to be aware of non-verbal elements of communication.

This interviewee was then interviewed separately by two pairs of law students playing the role of lawyers/interviewers (hereafter interviewers). Students were paired adversarially so that two law students formed a pair to play the role of counsel for appellants (defendants at first instance) and two law students formed a pair to play the role of counsel for the respondents (prosecutors at first instance). Both pairs of these counsel interviewed an interviewee, once only. That is, two interviewees each played the same role and each was interviewed by one pair of interviewers: one pair playing the role of defendant/appellant counsel; one pair playing the role of prosecution/respondent counsel. Resources would not permit the same drama student playing both roles for each interview by counsel for the appellants and for the defendants.

Neither pair of interviewers saw the written hypothetical given to the interviewee but was given brief details concerning the offence witnessed by the witness/interviewee. Each pair of interviewers was instructed to discover as many facts as possible from the interviewee by means of an interview, so that a fact scenario could be written by each pair of interviewers. That written product was then compared to the original written hypothetical given to the interviewee in order to provide each pair of interviewers with a standard by which they could measure their ability to discover facts through the process of interviewing. The use of a written hypothetical by the interviewee was expected to reduce the possibility of that interviewee departing too far from the set fact scenario when responding to interrogation by each pair of interviewers, thereby increasing the validity of the comparison between the set written hypothetical and that constructed by each pair of interviewers.

Written and oral arguments were then presented by each of these two pairs of interviewers in accordance with the existing mooting programme. That is, the two pairs of students interviewing the same interviewee's role for the interviewing project were opposed adversarially when writing and presenting arguments for the moot.

Demonstrations and instruction in the theory and practice of interviewing were given before students were required to conduct practice interviews. Assessable interviews then followed. All interviews were video-taped and videotapes also used to give feedback to students about their interviewing skills. Videotaping was possible only by means of a grant of $\$ 7500$ from the Law Foundation of South Australia Inc to purchase video equipment, specifically for this interviewing project. $^{92}$

The decision to pair students was made not only because mooting required pairs but also for resource reasons as well as to facilitate the ideals formulated in the search for conceptual foundations for interviewing. The expectation was that levels of cooperation and collaboration not otherwise attainable would occur.

\section{Assessment}

Competence and skills in interviewing were measured by law students using self-and peer-assessment, by drama students using peer-assessment and by criminal law teachers, all by means of an adaptation of the American Bar Association Criteria used in its interviewing competition. ${ }^{93}$ Choice of assessment was again made with expectations of fulfilling those ideals discovered as desirable during the search for conceptual justification of the change.

Law and drama students were given time at the completion of each interview to compile assessment forms, all of which were then considered during the course of the review of the videotape of the interview which was carried out with all four students playing both counsel roles. In this way, the potential for peerand self-assessment increased.

Pairing of students produced additional benefits for assessment. One was the ability to make a comparison between the respective fact scenarios discovered by each pair of opposing counsel during the interview. Since the basic facts in the written hypothetical were identical, assessment of students' ability to 
discover facts is enhanced, despite the different perspective of counsel for the appellant and of counsel for the respondent. Another benefit was the potential for cooperative learning whereby students learned from their peers as a consequence of the levels of cooperation and collaboration that were necessitated by the fact that students were paired. ${ }^{94}$

\section{CONCLUSION}

Although it is premature to comment upon results of the interviewing project described and justified above, it is appropriate to comment about two aspects: resource implications; and expectations regarding results.

\section{Resource Implications}

It should be noted here that the introduction of interviewing into the Criminal law course would not have been possible without the award of a National Teaching Development Grant (NTDG) for this purpose from the Committee for the Advancement of University Teaching (CAUT) ${ }^{95}$ This grant funded the employment of an additional staff member to specifically implement the project undertaken. ${ }^{96}$ There can be no doubt that the interviewing project could not have been launched and maintained without funding from that NTDG. In fact, it would not have been possible without significant input in time by one of the Criminal Law teachers additional to that funded by CAUT at the introductory stages, for the grant proved to be far short of that necessary. There can only be speculation regarding whether a more informed request for funding would have been met by CAUT, for the additional time required amounted to at least one third of the time paid for by the grant. There is no doubt that estimates of time needed, especially for student-sought direction and reviews of interviews, were underestimated.

\section{Expectations}

In addition to the benefits that flow from going beyond the mere "imparting of knowledge" it is anticipated that the addition of interviewing to the mooting programme in the criminal law course at the Flinders Law School of South Australia will achieve specific objectives, some of which follow.

1 Establish a basic level of communication skills, especially oral.

2 Demonstrate that skills practised specifically by lawyers are also applicable to other practice-based workers.

3 Create recognition of the importance of:

a) the place of interviewing in the continuity of legal theory and practice,

b) fact-finding to the theory and practice of law,

c) the application of legal principles to facts, and

d) the interconnections between all these facets of teaching and learning law.

Whether any of those objectives were achieved will be the subject of separate analysis and report in due course.

It can be seen that the overriding aim of the exercise described above was the demonstration of the existence of relationships and connections between all aspects of teaching and learning law by including the process of interviewing, which, by means of the skills and competencies applied in that process, is expected to create an understanding of law in context. By working towards making the teaching and learning of law contextual, humanistic, holistic, appropriately integrated with assessment and preferably problem-based, those objectives may be possible of achievement. Pending verification of results from the interviewing programme, one may speculate that there may be an intrinsic value attached to the inclusion of teaching and learning practical legal skills, especially by means of interviewing, because it should never be forgotten that what is excluded from law curricula invites judgments about those curricula as much as does what is included. ${ }^{97}$

* Lecturer in Law at the Flinders University of South Australia and barrister and solicitor of the Supreme Court of SA. My thanks to the anonymous referees for their critical contributions to this paper. All errors are, of course, mine.

1 D Pearce, E Campbell \& D Harding Australian Law Schools: A Discipline Assessment for the Commonwealth Tertiary Education 
Commission, A Summary and Volumes I-IV, (Canberra: AGPS 1987) at 24 and at 27-28. A study on the impact of the Pearce Report was commissioned by DEET and started in November 1992 by The Centre for The Study of Higher Education at The University of Melbourne. The report became available recently: C McInnis \& S Marginson Centre For The Study of Higher Education University of Melbourne Australian Law Schools After The Pearce Report (Canberra: AGPS 1994).

2 Note 1 at 26-28. I assume that to be legal work as practised by solicitors and barristers.

3 Note 1 at 28 and at 30-31. The teaching of such skills is also a recommendation contained in the Cramton Report (of the ABA Lawyer Task Force on Lawyer Competency 1979) and the McCrate Report (of the ABA Task Force on Law Schools and the Profession 1992): for details of and commentary on these reports see EE Clark, Legal Education and Professional Development An Educational Continuum, Report of The Task Force on Law Schools and The Profession: Narrowing the Gap, (Illinois: American Bar Association 1992), (1993) 4 Legal Educ Rev 201 at 208-212; NL Schultz, How Do Lawyers Really Think? (1992) 42 J of Legal Educ 57 at 57; JJ Costonis, The McCrate Report: Of Loaves, Fishes, and the Future of American Legal Education, (1993) 43 J of Legal Educ 157; NM Maurer \& LF Mischler, Introduction to Lawyering: Teaching First-Year Students to Think Like Professionals, (1994) $44 \mathrm{~J}$ of Legal Educ 96; R McCrate, Preparing Lawyers to Participate Effectively in the Legal Profession, (1994) $44 \mathrm{~J}$ of Legal Educ 89.

4 Although the terms "theory" and "practice" are used here to illustrate what is alleged to be a dichotomy between the teaching and learning of law in law schools and in practical legal training courses, I agree with the following commentators that this separation is more artificial than real: G Nash QC, Should Law Schools Produce Lawyers? (1991) 9 J of Professional Legal Educ 27, also presented to the Law Council of Australia Legal Education Conference at Bond University 13-16 February 1991; W Twining, Preparing Lawyers for the 21st-Century, 992) 3 Legal Educ Rev 1; D Weisbrot, Competition, Cooperation Legal Change, (1993) 4 Legal Educ Rev 1. That “gap” also exists in the U according to HT Edwards, The Growing Disjunction Between Legal Education and the Legal Profession, (1992) 9 Legal Educ 34 and JR Ostertag, Legal Education in Germany and the United States - A Structural Comparison, (1993) 26 Vanderbilt J of Transnational Law 301. On this "gap” see Symposium on the 21st Century Lawyer: Is There a Gap To Be Narrowed? (1994) 69 Washington Law Rev 505.

5 D Newble \& R Cannon A Handbook For Clinical Teachers (Lancaster MTP Press 1983); DA Schön Experiential Learning (New York: Basic Books 1983); D Boud \& D Walker, In The Midst of Experience: Developing a Model to Aid Learners and Facilitators, in R Harris \& P Willis (eds) Striking a Balance: Adult and Community Education in Australia Towards The Year 2000 (Adelaide: Centre for Human Resource Studies and Australian Association of Adult and Community Education 1992) 267; F Foley, Adult Education and The Labour Market, in R Harris \& P Willis (eds) id.

6 For example (1988-89) 5 Australian J of Law and Society and (1991) 9 Law in Context.

7 This journal and $J$ of Professional Legal Educ.

8 The Committee for the Advancement of University Teaching is a body established by the Department of Employment Education and Training for the purpose of supplementing "the efforts ... made by Australian universities to restore teaching and learning to their central place in academic culture”: Improving University Teaching (Canberra: AGPS 1993) at v. CAUT has awarded National Teaching Development Grants for innovations, and to recognise outstanding contributions, in teaching in universities since 1992 (awarded in 1992 for use in 1993 and so on).

9 Pearce Report Summary, supra note 1 at 34. An assertion supported in relation to the United Kingdom by J Macfarlane, Look Before you Leap: Knowledge and Learning in Legal Skills Education, (1992) 19 J of Law and Society 293 at 294 . And see Clark, supra note 3 at 220 .

10 JN Jackling \& N Gold, Academic and Practical Legal Education: Where Next? Part 1, (1986) 4 J of Professional Legal Educ 1-14 and Part 2, (1987) 4 J of Professional Legal Educ 72. And see J Goldring, Academic and Practical Legal Education: Where Next? An Academic Lawyer's Response to Noel Jackling \& Neil Gold, (1987) 5 J of Professional Legal Educ 105. Professor Goldring agrees that there is a need for a closer relationship between academic and practical education but not to the extent that students should be ready for private practice as suggested by Professors Jackling and Gold.

11 D Weisbrot, Legal Education, in Australian Lawyers (Sydney: Longman Cheshire 1990) at 135; Nash, supra note 4.

12 See Sir Anthony Mason CJ, Inauguration of the Faculty of Law at the University of Wollongong, (1991) 34 (2) The Australian Universities Rev 24, a paper originally presented at Wollongong on 19 February 1991; G Landsdell \& G Davis, Teaching Initiatives in The Murdoch University Law Programme, in MD Pendleton \& RL Simmonds (eds) Occasional Papers (Perth: Murdoch University School of Law 1991) 29; K Lauchland, Skills for the Masses: From the Cradle to The Grave, Paper presented at 4th Annual Conference of Australian Law Teachers Association in Brisbane 9-12 July 1992 1; MJ Le Brun, Law at Griffith University: The First Year of Study, (1992) 1 Griffith Law Rev 15; A Leaver, Flinders Law School Accepts Skills Challenge: Developing the Complete Lawyer, (1994) 16 (4) Law Society Bulletin of SA 33.

13 Graduate Diploma of Legal Practice, a postgraduate practical training course provided by the University of SA, a condition precedent to admission as a barrister and solicitor to the Supreme Court of SA as articles are not generally available in SA. That course has been under threat since 1992 by a lack of funds to the extent that it has, in 1994, been reduced in duration from one to one half of an academic year and become the Graduate Certificate of Legal Practice. It may not be available at all in 1996 if the University of SA withdraws funding, unless the Law Society assumes responsibility, which it has to some degree. See His Honour Mr Justice Perry, GDLP to Change in 1994, (1993) 15 (1) Law Society Bulletin of SA 27; From the President, PLT and the Winds of Change, (1993) 15 (3) Law Society Bulletin of SA 7; Society Steps in to Provide PLT, (1994) 16 (4) Law Society Bulletin of SA 25. See similar trends in other states as reported recently in Campus Review.

14 The Flinders University Law School Curriculum Planning Committee The Proposed LLB Curriculum at the Flinders University of South Australia 1991 at 5. By "foundation" was meant those practical skills described in the Pearce Report, Cramton Report and the McCrate Report: supra notes 1 and 3.

15 Mr Elliot Johnston QC, former Justice of the Supreme Court of South Australia and former Commissioner of the National Inquiry into Aboriginal Deaths in Custody.

16 A topic with a predominantly practical perspective running in tandem with another compulsory topic, Torts and Legal Principles which focuses upon theoretical principles including several critical perspectives.

17 I refer here to the common law theory of law as well as interdisciplinary perspectives necessarily imported by criminal law. Criminal law students acted in two groups as solicitors briefing counsel for the prosecution and counsel for the defence with guidance from the criminal law teachers. See B Donaghy, Criminal Law Comes Alive, (1993) 15 (4) May Law Society Bulletin of SA 24, reprinted from Campus Review. The trial was heard before His Honour Mr Justice Mullighan QC (of the Supreme Court of SA) to whom the Law School extends its gratitude for his cooperation and participation.

18 Mooting was given a weighting of 30\%. The balance of assessment was by means of essays (20\%), tutorial participation (10\%) and an end-of-year examination (40\%).

19 The course teachers' preference was for visiting practitioners as it is reasonable to expect their performance to be closer to the 
reality of hearings than that of teachers whose comparative experience must, of necessity, be less. This is especially the case with teachers who have neither practical qualifications nor practical experience.

20 However, moots are being eliminated from some topics as a result of the difficulty in balancing increasing student numbers and decreasing resources. See W Smith \& P Connor, Students Take Up Challenge for More ... Practical Legal Skills, (1993) 14 (3) April Law Society Bulletin of SA 14. It is interesting to note that the value of skills accepted as inherent in moots is also recognised by other practice-based professions: see R Smith, Using a Mock Trial to Make a Difficult Clinical Decision, (1992) 305 British Medical Journal 1284.

21 For examples see M Chesterman \& D Weisbrot, Legal Scholarship in Australia, (1987) 50 Modern Law Rev 709; C Sampford \& D Wood, Theoretical Dimensions of Legal Education - A Response to the Pearce Report, (1988) 62 ALJ 32; P Alldridge, What's Wrong With The Traditional Criminal Law Course? (1990) 10 Legal Studies 38; LD Solomon, Perspectives on Curriculum Reform in Law Schools: A Critical Assessment, (1992) 24 University of Toledo Law Rev 1.

22 D Boud, Green Guide No 5: Implementing Student Self-Assessment (Sydney Higher Education and Research Development Society of Australasia University of New South Wales 1986); Crooks TJ Green Guide No 8: Assessing Student Performance (Sydney: Higher Education and Research Development Society of Australasia University of New South Wales 1988); Boud D, Assessment and the Promotion of Academic Values, (1990) 15 (1) Studies in Higher Education 101; MJ Le Brun, Curriculum Planning and Development in Australia: Why is Innovation So Rare, (1991) 9 Law In Context 27.

23 Teaching and learning is examined jointly because my perception is that any expectation that these aspects can be considered separately in this context is as artificial as the expectation that the theory and practice of law can be separated.

24 For example, Le Brun, supra note 12.

25 A holistic and humanistic approach has been adopted at Griffith University Law Faculty: see B Dick, L Godden, K Healy \& MJ Le Brun with G Airo-Farulla \& D Lamb, A Case Study of the “Offices” Project (Teacher-Less, Cooperative Groups) at Griffith University: Implementing Educational Theory, (1994) 4 Legal Educ Rev, 273 at 274 and at note 3.

26 See HP Rickman (ed) Dilthey: Selected Writings (Cambridge Cambridge University Press 1991) at 22

27 See Le Brun, supra note 12 at 16.

28 AG Amsterdam, Clinical Legal Education — A 21st-Century Perspective, (1984) 34 J of Legal Educ 612.

29 See Maurer \& Mischler, supra note 3 at 107.

30 CE Engel, Problem Based Learning (1992) 48 British Journal of Hospital Infection 325.

31 K Mack, Bringing Clinical Learning into a Conventional Classroom, (1993) 4 Legal Educ Rev 89 at 91.

32 AWB Simpson, The Academic Study of Law in Invitation to Law (Oxford: Basil Blackwell 1988) 176. See also Boud \& Walker, supra note 5; R Johnstone, Rethinking The Teaching of Law, (1992) 3 Legal Educ Rev 17 at 30.

33 Also an obstacle in some circumstances. See DH Brundage \& D Mackeracher Adult Learning Principles and Their Application to Programme Planning (Ontario: Ministry of Education and Ministry of Colleges and Universities 1980) at 32. See also P Ramsden Effective Teaching in Higher Education, in J Bain J, E Leitzow \& R Ross (eds) Promoting Teaching in Higher Education: Reports from The National Teaching Workshop (Brisbane: Griffith University 1993) 39 at 39.

34 Note 31 at 101, citing PJ Spiegelman, Integrating Doctrine, Theory and Practice in The Law School Curriculum: The Logic of Jake's Ladder in The Context of Amy's Web, (1988) 38 J of Legal Educ 243 at 258.

35 Supra note 30 at 325.

36 SD Brookfield Understanding and Facilitating Adult Learning (San Francisco: Jossey Bass 1990) at 83.

37 J Mezirow, A Critical Theory of Adult Education and Learning, (1981) 32 Adult Educ 3, at 21. For a more recent analysis of selfdirected learning see R Harris, Reflections on Self-Directed Adult Learning: Some Implications for Educators of Adults, in Harris \& Willis (eds) supra note 5 at 177.

38 Le Brun, supra note 12 at 16.

39 Supra note 26 at 10-11, and see RJ Howard Three Faces of Hermeneutics (Berkeley University of California Press 1982) at 10.

40 Clark, supra note 3 at 212.

41 M Newman, The Role of The Adult and Community Educator in The Nineties, in Harris \& Willis (eds) supra note 5,121.

42 L Kobert \& M Tolan, Coming of Age in Nursing: Rethinking the Philosophies Behind Holism and the Nursing Process, (1990) 11 Nursing and Health Care 308. I use "feminine" rather than "feminist" because the view is that of women rather than the ideology of women: that is, women are other-regarding rather than competitive, as men are alleged to be. I acknowledge that this view can also be an element of cultural feminism.

43 C Gilligan In a Different Voice: Psychological Theory and Women's Development (Cambridge: Harvard University Press 1982).

44 A Giddens Uprooted Signposts at Century's End, (1990) 17 January The Higher 21. It is suggested that this assertion obtains notwithstanding the fad that postmodernism is concerned with deconstruction, that is separating the agenda of the writer/investigator from what is written/ investigated, because the process of deconstruction still recognises that the writer/investigator influences what is written/investigated. For a discussion of postmodemism see M Davies Asking the Law Question (Sydney: Law Book Co 1994) at 219-259.

45 J Watson Nursing Human Science and Human Care (Newark: Appleton Century Crofts 1989).

46 Supra note 30 at 326.

47 See C Sampford \& D Wood, Legal Theory and Legal Education — The Next Step, (1989) 1 Legal Educ Rev 107.

48 HS Barrows \& RM Tambly Problem-Based Learning: An Approach to Medical Education (New York: Springer 1980). On problem-based learning in a practice-based profession see D Newble \& RA Cannon Handbook for Clinical Teachers (Lancaster: MTP Press 1983).

49 For an overview of the use of problems in a law school in a manner closer to the requirements of Barrows problem-based learning see JC Moust \& HJ Nuy, Preparing Teachers for a Problem-Based Student- Centered Law Course, (1987) 5 J of Professional Legal Educ 16; JC Moust \& HJ Nuy, Students and Problem-based Learning, How Well Do They Fit in? (190) 8 J of Professional Legal Educ 97. For student-centered learning see Le Brun, supra note 12 at 25, note 21, citing Phillips \& Powers. For the application of problem-based learning in the Australian context see K Winsor, Toe In The Bathwater: Testing the Temperature with Problem-Based Learning, (1989) 7 J of Professional Legal Educ 1; S Nathanson, Creating Problems for Law Students: The Key to Teaching Legal Problem Solving? (1991) $10 \mathrm{~J}$ of Professional Legal Educ 1.

50 CL Ogden, The Problem Method in Legal Education, (1984) 34 J of Legal Educ 654.

51 Supra note 30 at 327. 
52 D Newble \& RM Clark, The Approach to Learning of Students in a Traditional and Innovative Problem-Based Medical School, (1986) 20 Medical Educ 267.

53 S Goodlad \& B Hirst (eds) Explorations in Peer Tutoring (Oxford: Blackwell 1990).

54 Supra note 30.

55 CE Engel \& RM Clark cited in Engel, supra note 30 at 326.

56 Supra note 30 at 325; JW Barnes, The Functions of Assessment: A Re-examination, (1990-91) 2 Legal Education Review 177 at 186, stating that the ability to deal with change in practice requires preparation at law school.

57 Supra note 50. See also N Rogers, Improving The Quality of Learning in Law Schools By Improving Student Assessment, (1993) 4 Legal Educ Rev 113 at 114-115.

58 DS Brookfield Understanding and Facilitating Adult Learning (San Francisco: Jossey-Bass 1990) at 263-4. See also JW Barnes, supra note 56 at 181; F McGlone, Optional Group Assignments - An Assessment Technique Which Encourages Cooperative Learning, Paper presented at Australian Law Teachers’ Association Conference, Christchurch, September 1993.

59 Barnes, supra note 56 at 178 and at note 11.

60 Barnes supra note 56 at 203.

61 Barnes supra note 56 at 179 quoting J Heywood, Assessment in Higher Education 1st ed (London: Wiley 1977) at vii.

62 S Rawson \& AL Tyree, Self and Peer Assessment in Legal Education, (1989) 1 Legal Educ Rev 135 at 137, quoting D Boud \& J Lublin Self Assessment in Professional Education: A Report to the Commonwealth Education and Research and Development Committee (Kensington: University of New South Wales Tertiary Education Research Centre 1983).

63 See Rogers, supra note 57 at 140, reporting the results of a survey of students' perceptions of learning.

64 P Ramsden Learning to Teach in Higher Education (Melbourne: Routledge 1992) 210.

65 Barnes, supra note 56 at 181 citing G Bergenhenegouwen, Hidden Curriculum in the University, (1987) 16 Higher Educ 535.

66 Supra note 1 at paras 3.50-3.52. Apparently also still the "normal pattern" in the UK. See J Wilson, A Third Survey of University Legal Education in The United Kingdom, (1993) 13 Legal Studies 143 at 181.

67 McInnis \& Marginson, supra note 1 at 167.

68 Barnes, supra note 56 at 208.

69 Supra note 22 at 18. It is interesting to note that the philosophy of the Higher Education and Research Development Society of Australia includes the "notion of self-assessment, or reflective self-improvement": see P Candy, HERDSA - Supporting The Improvement of University Teaching, in J Bain, E Leitzow \& R Ross (eds) Promoting Teaching in Higher Education (Brisbane: Griffith University 1993) 25 at 27.

70 Rawson \& Tyree, supra note 62 at 136.

71 See RD Linke (Chair) DEET Report on Performance Indicators in Higher Education (Canberra AGPS 1991).

72 Final Report of the Working Party on Quality in Teaching and Learning Adelaide University of Adelaide April 1993; Quality Guide (Adelaide University of Adelaide September 1993); the Quality Portfolio Vols I and II (Adelaide The Flinders University of South Australia September 1993).

73 See note 72, Quality Guide (Adelaide University of Adelaide September 1993) at 2.

74 See GA Jaquish \& J Ware, Adopting an Educator Habit of Mind: Modifying What it Means to Think Like a Lawyer, (1993) 45 Stamford Law Rev 1713 at 1715-1716.

75 JO Mudd, Academic Change in The Law Schools Part I, (1993/94) 29 Gonzaga Law Rev 29 at 49 note 64.

76 Supra note 31 at 95. See also RL Simmonds, Legal Education of Future Professional in a University, (1991) $9 \mathrm{~J}$ of Professional Legal Educ 37 for argument supporting the placement of legal education in law schools.

77 A Bradney, The Place for Teaching Professional Legal Skills In United Kingdom University Law Schools, (1987) $5 \mathrm{~J}$ of Professional Legal Educ 125. See also note 12, regarding innovations in Australian law schools.

78 Cramton Report, supra note 3 at 9-10. Also cited in L Stuesser, Skills for the Masses: Bringing Clinical Skills to More Students at Less Cost, Paper presented at 4th Annual Conference Australian Law Teachers Association Brisbane 9-12 July 1992 at 5-6 and published in (1991) 10 (2) J of Professional Legal Educ 119.

79 C Menkel-Meadow, The Legacy of Clinical Education: Theories About Lawyering, (1980) 29 Cleveland State Law Rev 555 at 556.

80 A Sherr Client Interviewing for Lawyers (London: Sweet \& Maxwell 1986) at 2. See also A Sherr, Lawyers and Clients: The First Meeting, (1986) 49 Modern Law Rev 423. Professor Sherr is Director of Legal Practice at the University of Warwick, England.

81 As a voluntary exercise at an informal level.

82 Supra notes 30 and 33. See also Brookfield, supra note 58 at 23, quoting EL Simpson, Adult Learning Theory: A State of The Art in H Lasker, J Moore \& EL Simpson (eds) Adult Development and Approaches To Learning (Washington National Institute of Education 1980).

83 J Hayes, All For Justice — Justice For All, (1993) 143 (6614) New Law Journal 1221. Hayes is Secretary-General of the Law Society of United Kingdom.

84 Supra note 83.

85 Supra note 14. By foundation is meant those skills which are pre-requisites to learning others. For example, skills required for examination-in- chief, cross-examination and re-examination are unlikely to develop satisfactorily in the absence of some practice and grounding in the asking of questions during interviewing.

86 Supra note 80 at 7.

87 Supra note 20, Smith \& O’Connor. Also supported by the results of evaluations of interviewing and mooting programmes completed by law students at the Law School of the Flinders University of SA in 1993.

88 Pearce Report Summary, supra note 1 at 30-31.

89 Recently re-affirmed by the English Court of Appeal: see $R v R 26$ January 1994 in S Enright, Crime Brief, (1994) 144 New Law Journal 1245 .

90 So seriously that at the completion of one interview both interviewers were in tears in sympathy with the "witness", also in tears!

91 For an overview of semiotics in the context of law see M Davies, supra note 44 at 229-240. Drama students at Flinders University have played client roles for medical and social work students for some time, viewing this participation as practice. There were no 
formal benefits planned from this project for the drama students other than providing opportunities to practise roles not otherwise possible in the course of their studies. Plans are in hand to integrate formally this level of participation by drama with law students into the curriculum of drama students in 1995.

92 Thanks to the Law Foundation Inc, the Law School now has two sets of cameras, recorders and monitors, all of which will remain the property of the Law School. On the merits of videotaping in teaching and learning see DA Gillies \& DA Child, Learning from Management Videos: The Producers' Point of View, (1990) 15 Nurse Educator 15; P Barnard, Using Video as a Reflective Tool in Interpersonal Skills Training, (1991) 11 Nurse Educator Today 143; PN Meyer, Visual Literacy in the Legal Culture: Reading Film as Text in the Law School Setting, (1993) 18 Legal Studies Forum 73.

93 See DL Zorn, Some Suggestions for Successful Interviewing in the ABA Client Counselling Competition, (1985) 18 Creighton Law Rev 1443 at 1449-1458. The same criteria are used in the Australian Interviewing Competition.

94 Peer-learning facilitates the development of self-directed learning by encouraging both informal and formal levels of cooperation and collaboration: see Brookfield, note 36 at 83 and at 135-143 for a discussion on the effects of groups. For commentary on group teaching and learning generally see G Brown \& M Atkins, Effective Small Group Teaching, Effective Teaching in Higher Education (London: Methuen 1988) at 50-90. In relation to law, see RM Reed Group Learning in The Law School, (1984) 34 Journal of Legal Education 674, McGlone, supra note 58; Johnstone, supra note 32 at 49.

95 Supra note 8.

96 The format followed to some extent the concept of "team teaching” where two teachers instruct at the same time. See S Knights, J Sampson \& S Olona, Team Teaching, in Harris \& Willis (eds) supra note 5, 304. In this case, the two at Flinders were myself and David Bamford, the practitioner employed specifically for the interviewing project. The Project Group initially included Professor Rebecca Bailey-Harris \& Martin Hinton, but their continued participation was interrupted by the departure of the former for England and the involvement of the latter in other projects.

97 Since this paper was written a major work on improving student learning in law has been published. Readers are directed generally to M Le Brun \& R Johnstone, The Quiet (R)evolution (Sydney: Law Book Co, 1994). 